\title{
Alterations in Organ Weights of Mice after High Altitude Exposure*
}

\author{
Hiroshi Sawazaki \\ Faculty of Agriculture, University of Tokyo, Tokyo 113
}

(Received July 19, 1972)

\begin{abstract}
Male and female mice of the ICR-JCL strain born at sea level were weaned at the third week after birth and divided into five groups at random. Each group was taken to five experimental stations, at sea level and $770 \mathrm{~m}, 1,400 \mathrm{~m}, 2,000$ $\mathrm{m}$ and $2,600 \mathrm{~m}$ above sea level respectively, where they were fed for seven weeks until the tenth week after birth. They were returned to sea level at this time, and were necropsied at the eleventh, fifteenth and twenty-second weeks after birth. Weights of the brain, heart, liver, kidney, spleen, adrenal gland and gonad were measured. Influences of high altitude exposure were studied by analysis of variance concerning these measurements in organ weight per body weight $(\%)$.

Results obtained were as follows: Weights of heart (in males and females), adrenal gland (in females) and kidney (in males) increased in groups exposed at $2,000 \mathrm{~m}$ and $2,600 \mathrm{~m}$ above sea level, at the eleventh week after birth. Increasing patterns of heart weight influenced by altitude, differed in each litter, depending on their sensitivities. The mice reared at high altitude environment during their raising term, their gains of body weights after returning to the sea level station were greater than that of those which remained at sea level. Especially in female mice at the twenty-second week after birth, the difference between both groups was significant remarkably. Adrenal gland weight increase, influenced by altitude exposure, appeared to be reversible and disappeared in a short period after returning to sea level.
\end{abstract}

At the present time, the feeding area of domestic animals in Japan is shifting towards the mountainous regions. For practical application of these environments in the animal management, fundamental studies, on the influences of altitudes and the adaptability of animals, must be performed.

Studies on the mechanism of adaptability to high altitude environments were published as early as 1875, and many systematic surveys of high altitude natives and experimental studies on adaptability of men and animals have appeared since $1950^{1,2}$.

Many of these works concerned altitudes from $3,000 \mathrm{~m}$ to $6,000 \mathrm{~m}$ above sea level or on the mechanism of high mountain diseases ${ }^{3,4,5)}$. Especially in cattle, these studies were limited to the Brisket Disease ${ }^{6-12}$. These works reported the dysfunction of the cardiorespiratory system, such as pulmonary hypertension or right ventricular hypertrophy, and/or renal or liver functions, as a result of low pressure and low oxygen tension in the high altitudes.

* This work was supported by a Grant from the Ministry of Education in 1968, 1969 and 1970 . 


\section{SAWAZAKI}

Cardiac hypertrophy is an important change effected by high altitude exposure, but this change is not observed in environments under $3,000 \mathrm{~m}$ above sea level.

In Japan, the altitudes being developed for animal feeding are expected to be restricted to areas from $500 \mathrm{~m}$ to $2,000 \mathrm{~m}$ above sea level. In the cattle reared at altitudes from $1,400 \mathrm{~m}$ to $1,600 \mathrm{~m}$, cardiac hypertrophy was observed in electrocardiograms of sixty percent of the animals but no circulatory disturbances were observed ${ }^{13,14}$.

\section{Materials and Methods}

The present experiment was carried out for two years from 1968 to 1969 . Male and female mice (ICR-JCL strain), born at sea level (Tokyo), were weaned at the third week after birth, and divided into several groups at random. These mice were carried to the experimental stations by the car (about six hours travelling time), and thereafter were exposed for seven weeks. Courses by car was selected so as to avoid passing higher altitudes than the area of exposure. At the tenth week after birth, the animals were returned to sea level station by the same routes. At the eleventh, fifteenth and twenty-second weeks after birth, the animals were necropsied and organ weights of the brain, heart, liver, spleen, kidney, adrenal gland and gonad were measured.

In 1968, one hundred and fifty-six mice (75 males and 81 females) were produced in fifteen litters at sea level, and distributed to the stations at altitudes of $770 \mathrm{~m}$ (Ina), 1,400 m (Kiyosato), 2,000 $\mathrm{m}$ (Utsukushigahara) and 2,6000 $\mathrm{m}$ (Komagatake). These animals were necropsied at the eleventh week after birth. In 1969, three hundred and twenty-one mice (157 males and 164 females) were produced in twenty-six litters at sea level, and from these mice, one hundred and eighty (90 males and 90 females) were selected and divided into nine groups at random. Three groups each were distributed to the stations at altitudes of $770 \mathrm{~m}$ and $1,400 \mathrm{~m}$. After returning to the sea level station at the tenth week after birth, each group was necropsied at the eleventh, fifteenth and twenty-second weeks after birth respectively.

Differences among the altitude exposed were examined closely by analysis of variance $(\alpha=0.05)$ of the measurements. Five mice were reared in each alminium cage covered with wood shreds, and were given water and food pellets.

\section{Results and Discussion}

The four experimental stations are located in the mountainous areas of the Central Alps in Japan, and their meteorological environments are characteristic of higher altitudes in Japan.

A correlation chart between body weight and heart weight of the wild mice (Apodemus specicus and Microtus montebelli), trapped in an experimental station at $1,400 \mathrm{~m}$ above sea level, and of the ICR-JCL strain laboratory mouse is shown in Fig. 1 . Heart weights of the wild mice are relatively greater than those of the laboratory mice born at sea level. In Rattus norvegicus and Apodemus argenteus captured at various altitudes, heart weights became greater in proportion to the altitude ${ }^{15,16)}$. It is presumed that the right ventricular hypertrophy in these cases is a morphological change due to adaptation to the low oxygen tension environment of high altitudes. Using the mouse, cardiac hypertrophy effected by the high altitude exposure is expected to be observed. 
Organ Weights after High Altitude Exposure

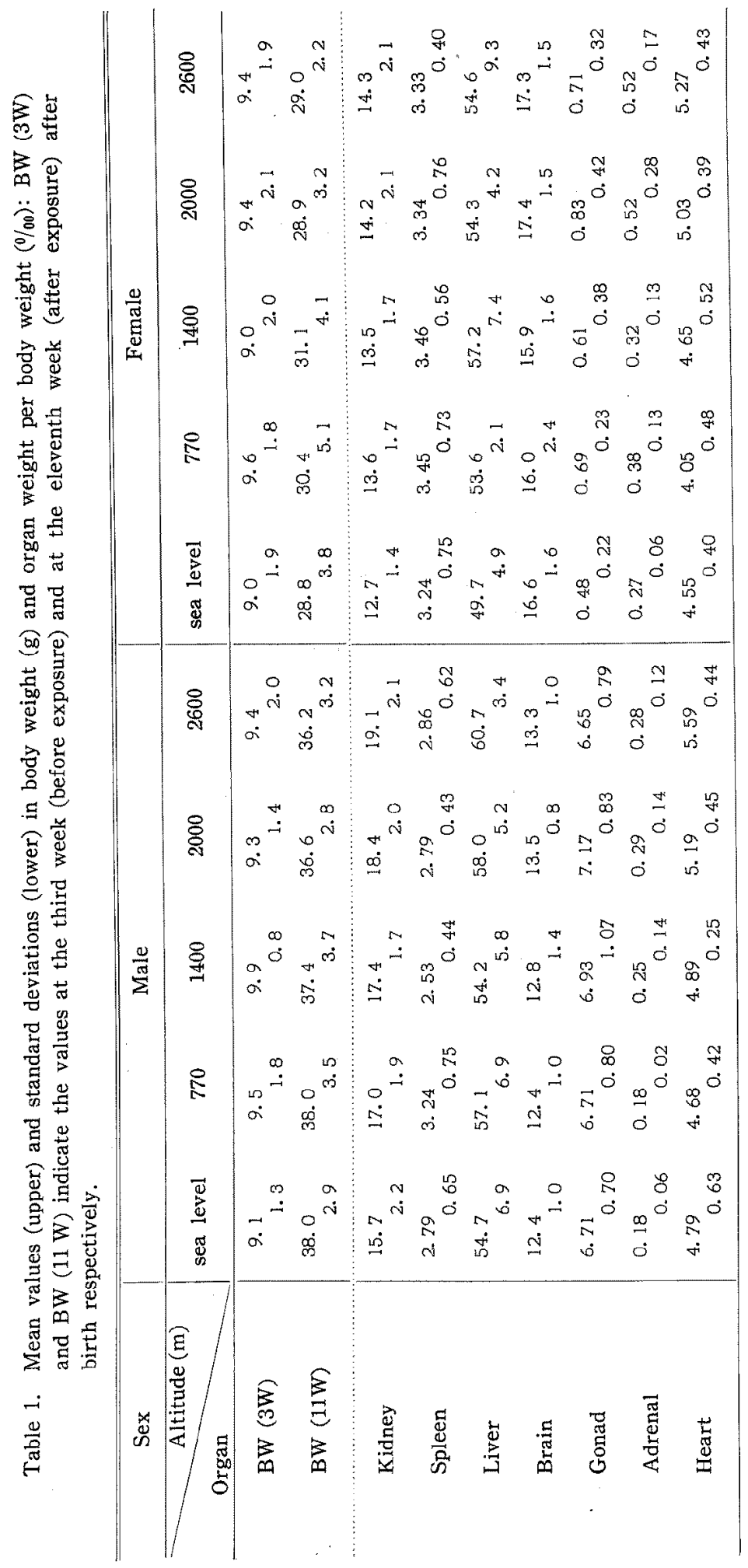




\section{SAWAZAKI}

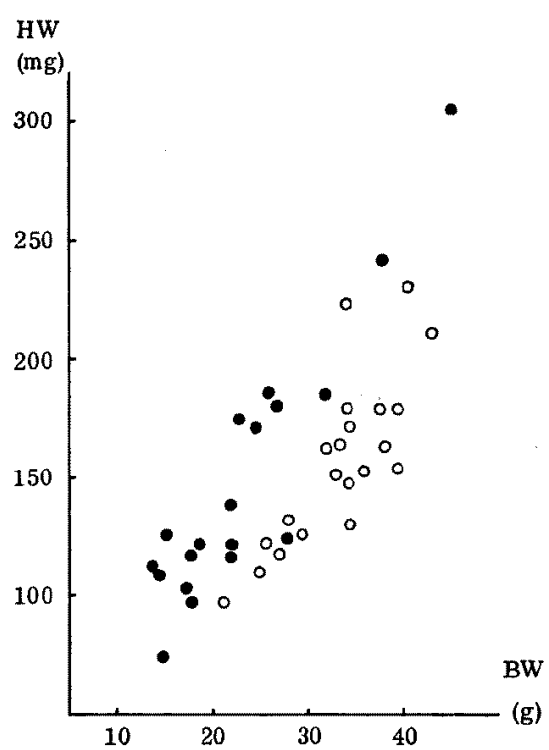

Fig. 1. Correlation chart between heart weights and body weights in wild mice trapped at $1,400 \mathrm{~m}$ altitude $(\mathbf{O})$ and laboratory mice reared at sea level $(O)$.

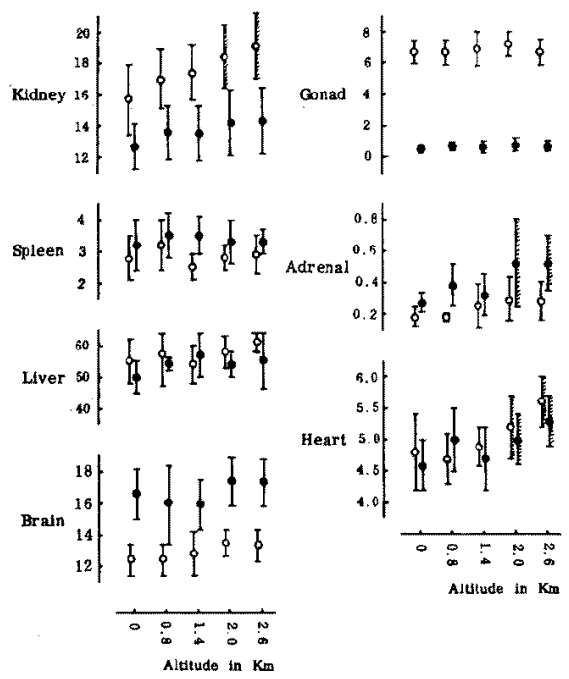

Fig. 2. Relationship between the organ weight per body weight (\%o) and altitude $(\mathrm{km})$ at the eleventh week after birth. $(0$ male, female, $M \pm S$. D.). The hatchings indicate the sig-ificant differences.

The Table 1 shows the organ weights at the eleventh week after birth, one week after the mice had been returned from the experimental stations to sea level. No differences are recognized in Dody weights at the third week after birth before exposure, in any groups and 
sexes. Sexual differences appeared clearly at the eleventh week after birth after exposure, but differences among the altitudes are not significant. The relationship between the organ weight per body weight (\%) and the altitude is illustrated in Fig. 2. Changes of the organ weights caused by the high altitude exposure are seen in the kidney (in male), the adrenal gland (in female) and the heart (in both sexes). These changes appeared over $2,000 \mathrm{~m}$ above sea level which is a very important phenomenon. This result is the same as for wild mice ${ }^{15,16}$. The high mountain disease of cattle is not found under $7,000 \mathrm{ft}(2,100 \mathrm{~m})$ above sea level ${ }^{12}$.

When the rat was exposed at $3,450 \mathrm{~m}$, the body weight decreased at the initial stage, but thereafter it increased. The length of the period reduced body weight increased with age and body weight. Therefore the duration of decreasing period of the body weight was evaluated as a parameter of adaptability to the high altitude environment ${ }^{17}$. In several works, it was reported that the testis and ovary weight per body weight decreased when the rat was exposed to a $25,000 \mathrm{ft}(7,500 \mathrm{~m})$ simulated altitude ${ }^{18}$, and there was a significant reduction in rate of reproduction although there were no structural alteration in the primary sex organs when the rat was exposed to an $18,000 \mathrm{ft}(5,400 \mathrm{~m})$ simulated altitude $\left.{ }^{19}\right)$. A prolonged sojourn of the rat at a $3,450 \mathrm{~m}$ altitude did not have any undesirable influence on their growth or ovarian cycle ${ }^{20}$ ). In studies of the breeding performance of Sonoran deor mice maintained for two years at an altitude of $3,800 \mathrm{~m}$, the $\mathrm{F} 2$ litter size at the high altitude was smaller in number than that at sea level because the incidence of cannibalism of newborn litters at the altitude was much greater than that at sea level21). When the guinea pig was exposed for twenty minutes per day at an $14,000-18,000 \mathrm{ft}(4,200-5,400 \mathrm{~m})$ simulated altitude, heart and kidney weight per body weight increased ${ }^{22)}$. After 35-cay old rats born at sea level were transferred for ten months to an altitude of $12,470 \mathrm{ft}(3,700 \mathrm{~m})$, the weights of their heart and adrenal gland increased, and especially in F2, the cardiac hypertrophy was remarkable ${ }^{23)}$. Rat, mouse, guinea pig and rabbit were exposed to altitudes of $4,700 \mathrm{~m}$ above sea level, liver damage was observed and the body weight decreased ${ }^{2 a}$.

Judging from these reports and the results obtained here, the extent of reaction will differ depending on the altitude, but it is presumed that the critical altitude for these reactions is about $2,000 \mathrm{~m}$ above sea level. No dysfuction was observed until $2,600 \mathrm{~m}$ in altitude, but because of the incidence of functional disorders, it was possible that a threshold pressure

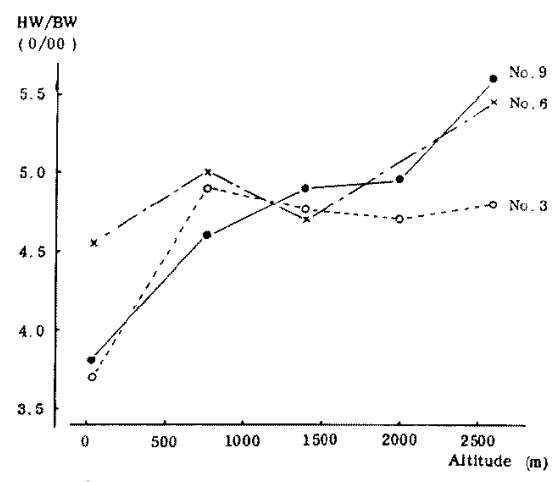

Fig. 3. Several patterns of reaction in heart weight per body weight, caused by the sensitivity of litters. (No. 3,6, 9 indicate the litter numbers) 


\section{SAWAZAKI}
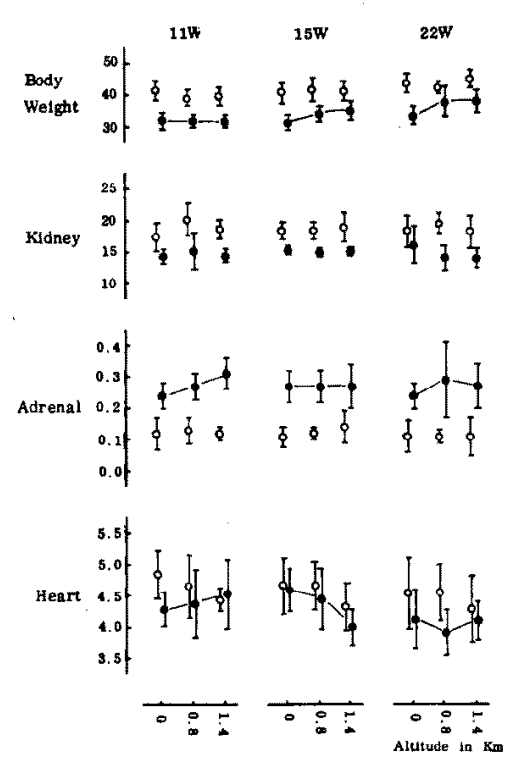

Fig. 4. Body weights and organ weights per body weights $(\%)$ of male (O) and female (O) mice at the eleventh, fifteenth and twenty-second weeks after birth. (M \pm S.D.)

existed for acclimatization of the living body ${ }^{25}$. Under $2,600 \mathrm{~m}$ above sea level, as shown in Fig. 3, several patterns of reaction were recognized in the exposed mice, caused by the sensitivity of litters. Based on the fact that the heart weight increased in proportion to the altitude ${ }^{16)}$, reactions under $2,000 \mathrm{~m}$ above sea level should be studied in more detail.

During one, five and twelve weeks after returning to sea level from altitudes of $770 \mathrm{~m}$ and $1,400 \mathrm{~m}$, the body weight of exposed female mice increased more than at sea level as time went on, as shown in Fig. 4. Adrenal gland weight of female mice exposed to high altitudes was much higher than that at sea level at the eleventh week after birth, but at the fifteenth or twenty-second week after birth, these differences disappeared. This indicates that the adrenal gland weight increase in exposed mice is reversible. It has been reported that changes in adrenal gland and thymus weight in rats maintained at $3,800 \mathrm{~m}$ altitude for ten months are reversible, but the cardiac hypertrophy of these rats is a permanent change ${ }^{26}$. Therefore, it may be interpreted that the alteration of the heart is different from that of the adrenal gland. The morphological and functional alterations of the heart in these individuals will be discussed in detail in the next report.

\section{References}

1) Hartado, A., Ann Int Med 53: 247-258. 1960.

2) Hartado, A., The Physiological Effects of High Altitude 1-7. Pergamon Press. Oxford. 1964.

3) NAIR, C. S., and S. George, Int J Biometeor 16: 79-84. 1972.

4) NAEYe, R. L., Circulation Res 16: 33-38. 1965. 
5) Arias-Stella, J., and S. Recavarren, Am J Pathol 41: 55-64. 1962.

6) Alexander, A.F., and R. Jensen, Am J Vet Res 20:680-689. 1959.

7) Alexander, A.F., D.H. Will, R.F. Grover, and J.T. Reeves, Am J Vet Res 21: 199-204. 1960.

8) Alexander, A.F., and D.H. Wrll, Biometeorology Vol. 2, Part 1. 161-167. Pergamon Press. Oxford. 1967.

9) Will, D. H., A.F. Alexander, J.T. Reeves, and R.F. Grover, Circulation Res 10: $172-177$. 1962.

10) Hecht, H. H., H. Kuida, R.L. Lange. J.L. Thorne, and A.M. Brown, Am J Med 32: 171-183. 1962.

11) Alexander, A.F., D.H. Will, and W.A. Wolff, Am J Vet Res 26: 1042-1046. 1965.

12) Jungmann, H., Biometeorology Vol. 2, Part 1. 208-213. Pergamon Press. Ōxford. 1967.

13) Kanematsu, M., K. Kibe, K. Sekikawa, S. Nomura, H. Sawazaki, Y. Shimizu, A. Ōkanda, and Y. Senoo, J Jap Soc of Grassland Sci 14: 56-76. 1968.

14) Sawazaki, H., T. Ibaraki, M. Tokuriki, U. Kaseda, S. Nomura, K. Sekikawa, and M. Kanematsu, Jap J Zootech. Sci 41 : 151-155. 1970. (in Japanese)

15) Ueda, G., T. MiYao, A. Sakal, and Y. Yanagidaira, J Growth 7 (2): 1-10. 1968. (in Japanese)

16) Sakal, A., and T. Motoyama, J Growth 7 (4): 1-11. 1968. (in Japanese)

17) Weine, W. H., Biometeorology Vol. 2, Part 1. 219-225. Pergamon Press. Oxford. 1967.

18) Altuand, P. D., J Exp Zool 110: 1-17. 1949.

19) Altland, P. D., Physiol Zool 22: 235-245. 1949.

20) Wrihe, W. H., H. Brezowsky, and H. Schwarzenzach, Pflügers Arch ges Physiol 273: 514527. 1961.

21) SAwin, C. F., Am J Physiol 218: 1263-1266. 1970.

22) Van Liere, E. J., Am J Physiol 116: 290-294. 1936.

23) Timiras, P.S., A.A. KRUM, and N. PAcE, Am J Physiol 191: 598-604. 1957.

24) Chiodi, H., The Physiological Effects of High Altitude 97-113. Pergamon Press. Oxford. 1964.

25) ClegG, E.J., and G. A. Harrison, Biometeorology Vol. 2, Part 1. 184-190. Pergamon Press. Oxford. 1967.

26) Timiras, P.S., The Physiological Effects of High Altitude 21-31. Pergamon Press. Oxford. 1964.

\section{高海抜環境曝露によるマウス臓器重量の変化}

$$
\text { 沢崎坦 }
$$

\section{東京大学農学部, 東京都 113}

平地で生産した ICR-JCL 系マウスを, 生後3 週令で 離乳，無作為的に 5 群に区分し，海抜の罢なる 5 力所 (平地, $770 \mathrm{~m}, 1,400 \mathrm{~m}, 2,000 \mathrm{~m}, 2,600 \mathrm{~m}$ ) k配犆し て 10 週令要での 7 週間に亘って飼育した. 10 週令で平 地に回取, 生後 11 週令, 15 週令および 22 週令で剖検 し, 脳, 心, 肝, 腎, 脾, 副腎および生殖腺の重量を計 測，分散分析法により，高海抜環境嚗露の影郘を観察し た、結果はつぎのとおりである。

1) 平地へ回收後 1 週間を経過した生後 11 週令では,
海抜 $2,000 \mathrm{~m}$ 以上で飼育されたマウスの心(雌雄), 副 腎 (雃), 腎 (雄) の重量が増加する，2）曝露による心 重量の增加は，母マウスによって反応のパターンが相違 し，感受性の差によると考えられる，3）育成期定高海 拔環境下で経過したマウスは，平地へ回収後に增体量を 増し，とくに雌では，平地で飼育されたものと比べ，生 後 22 週令で明暸な差が生ずる。4）曝露による副腎重 量の增加は，平地一回収後短時日の間に消退し，心重量 の增加とは样相を異にする。 